\title{
The Use Of Metacognitive Scaffolding To Improve College Students' Academic Success
}

\author{
Ioney James, North Carolina A \& T State University, USA
}

Comfort O. Okpala, North Carolina A \& T State University, USA

\begin{abstract}
In this era of accountabilities and complex ecologies, it is important to highlight results from metacognitive scaffolding, aimed at enhancing the learning strategies of a group of college freshmen preparing for the Praxis 1 examination. The purpose of this study was to analyze the impact of the use of metacognitive scaffolding used to enhance the literacy skills of 35 college students on their performance as measured by their test scores in Praxis 1 examination. It focuses on the importance of learning strategies to academic success, and literacy challenges encountered by college students. The result from the study indicates substantial improvement in students' literacy performance on Praxis 1 examination.
\end{abstract}

\section{INTRODUCTION}

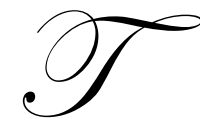

his proposal highlights metacognitive scaffolding used to enhance the literacy skills of a group of college freshmen preparing for the Praxis 1 examination, a benchmark for entry into the Teacher Education program. The following research questions guided the focus of the study:

- Did the use of metacognitive scaffolding improve the achievement of students as measured by Praxis I examination?

- What are the perceptions of students about the Praxis Preparation class?

- What are some of the literacy challenges faced by students in preparation for Praxis examination?

\section{THEORETICAL PERSPECTIVES}

This study was based on research constructs on teacher preparation and literacy. Teacher preparation is a measure of the quality of teacher education institution. Basic to the hot debate on teacher quality is the question of how teachers are prepared. The preparation of teachers varies among states and the variation ranges from the appropriate length of teacher education program, the contents to be taught, to the number of semester hours in general education program (Onstein \& Levin, 2003). Gregorian (2001) stresses that one of the most fundamental complaints of poor quality teaching in schools today can be attributed to teachers' preservice learning. Each year, a large number of high school students enter college lacking the effective learning strategies to matriculate through the college curriculum. Because most of these students encounter difficulty meeting the demand of the college courses, they are likely to develop negative attitudes toward learning and ultimately drop out of college after the first year.

In 2007, over 30\% of college students leave after the first year and almost 50\% never graduate, according to the Department of Education. Of the ranking of variables cited for student dropouts, education disqualification is $28 \%$. Retention of college freshmen and sophomores is a challenging task facing many institutions throughout the United States. In most colleges, students are asked to participate in the orientation process and are assigned advisors. Nevertheless, they lack the cognitive strategies necessary to succeed on qualifying examinations that are used as benchmark at different phases of their programs. 
Carbo (2008) argued that for our students to achieve high reading gains and become lifelong learners, they must acquire comprehension skills and be encouraged "to use more of their natural brain power to learn and remember what they read. More importantly, to achieve academic success, college students must acquire metacognitive knowledge in reading. Metacognitive knowledge involves the reader's awareness, monitoring, and guidance of his/her cognitive processing when constructing meaning from text (Garner, 1990, and Nist \& Holschuh, 2000).

Instructors are therefore being encouraged to engage students in effective learning process and help them regulate their thinking by modeling the metacognitve strategies necessary to attain academic success. Researchers have emphasized that to engage students in the learning process, college instructors must avoid assumptive teaching, consider the linguistic demands of texts and foremost, offer explicit instruction in effective learning strategies (Rachal, Daigle \& Rachal, 2007; Thompson \& Green, 2002; and Richardson, Morgan \& Fleener, 2009). This paper reports on some of the metacognive scaffolding that was used to engage students in deep and thoughtful interaction with texts.

\section{METHOD}

This study was designed around a semester course and aimed at helping a group of pres-service teachers incorporate metacognition strategies to improve comprehension of text. The participants for the study were the 35 pre-service teachers enrolled in the school of education. These students were required to pass Praxis 1 before being admitted to Teacher Education. The participants were enrolled in a Praxis Preparation class where they were introduced to various metacognitive strategies that were used to engage students in reading and writing. Some of these frameworks include the Question-Answer- Relationships-Q-A-R (Raphael, 1986), the Facts, Question and Response F-Q-R (Harvey and Goudvis , 2002), samples of anecdotal recordings of students' reflections on the strategies they used to construct meanings from texts, and conferencing, composing, and learning. Suggestions on how to further enhance performance were offered. Documents of the mock Praxis and actual Praxis 1 examinations were analyzed to determine the impact of metacognitive strategies on the participant's performance as measured by Praxis 1 examination.

The participants were assigned various reading passages during the first week of the program. Based on their performance from this activity, the instructors were able to plan and implement various metacognitive strategies to enhance their reading. Some of these strategies included one-on-one conferencing, questioning, modeling metacognitive strategies and, most of all, they were given ample opportunities to practice strategies in class. Information on student performance from their Mock Praxis examination was monitored and used to inform instruction. In addition to instruction, students had access to PLATO software to practice reading skills. Students also responded to a survey that assessed their perception of the Praxis Preparation class. All the participants took the Praxis I examination at the end of the semester.

\section{ANALYSIS}

Multiple sources of data were analyzed to answer the three research questions for the study. For question one, data from students' pre and post-tests, as well as the analysis of their reflection journals and their scores on Praxis I examination, were used to answer the question. Data from the post-test show an improvement in the participants' scores, which is an indication that they used metacognitive strategies. An analysis of their reflection journals shows that they were able to connect text information to prior knowledge as well as the strategies they use to progress throughout their course. Data from the Praxis I examination show an improvement as $80 \%$ of the students passed the Reading component of the Praxis I exam.

Data from the survey instrument were used to answer question number two. The participants' perceptions about the Praxis Preparation class varied. The majority of the participants indicated that the class was very useful in sharpening their reading skills in that particular class, as well as other classes. Students also stated, "The class helped me a lot." and "It made me aware of strategies to improve my writing and reading." One participant stated, "This class is the reason that I am going to pass." Another one responded, "This class is taking me back to grade school and preparing me for all of the reading skills that I have forgotten." 
Data from survey instrument, conferencing, pre- and post-tests and observations were used to determine the literacy challenges encountered by participants. These challenges include failure to regulate their thinking and learning process, their inability to develop systematic patterns for preparing for tests, inability to use their academic strengths to develop additional skills, and understandings of materials from various sources. Other challenges included their inability to monitor progress, time management, and lack of reading comprehension skills.

\section{CONCLUSION}

The data indicates substantial improvement in students' literacy performance on PRAXIS 1 examination. The initiative offers many ways in which instructors can engage their students in the learning process by modeling of metacognitive strategies. More than ever, the need to consider the skills that students bring to the learning setting is vital. Also, college students have myriad opportunities to experience academic success when self- regulating their learning was utilized.

\section{AUTHOR INFORMATION}

Ioney James is an Associate Professor in the Department of Curriculum and Instruction at North Carolina Agricultural and Technical State University where she teaches a number of reading courses to graduate and undergraduate students. She received her Ph.D. in 1999 from SUNY, Albany, New York. Her research interests include the literacy instruction of struggling learners and the literacy experience of immigrant minority students in the classroom. She can be contacted at the School of Education, Proctor Hall, 1601 E. Market St, NC 27411.

Dr. Comfort Okpala is an Associate Professor in the Department of Human Development and Services. Dr. Okpala has a variety of educational publications in key educational journals like the Journal of Early Childhood, Journal of Education Finance, Journal of Educational Researcher, Urban Education, Journal of Applied Business, Journal of Negro Education, Journal of College Teaching and Learning, and Contemporary Issues in Education Research. She has presented her research work in local, state, national and international conferences like American Education Finance Association (AEFA), American Evaluation Association (AEA), American Education Research Association (AERA), and others.

\section{REFERENCES}

1. $\quad$ Carbo, M. (2008). Best practices for achieving high, rapid reading gains. The Education Digest 73(7) 5760 .

2. Garner, R. (1990). When children and adults do not use learning strategies: Toward a theory of settings. Review of Educational Research, 60, 517-529

3. Gitomer, D., Latham, A., \& Ziomek, R. (1999). The academic quality of prospective teachers: The impact of admissions and licensure testing. Princeton, NJ: Educational Testing Service.

4. Gregorian, V. (2001). Teacher education must become colleges' central preoccupation. The Chronicles of Higher Education, B7.

5. Harvey, S. \& Goudvis, A. (2002). Strategies that work: Teaching comprehension to enhance understanding. ME: Stenhouse.

6. Johnson, J., Musial, D., Hall, G., Gollnick, D., \& Dupuis, V. (2005). Introduction to the Foundations of American Education. Boston, MA: Allyn and Bacon.

7. Nist, S. L. \& Holschuh, J. (2000). Active learning strategies for college success. Boston: Alyn \& Bacon.

8. Ornstein, A., \& Levin, D. (2003). Foundations of education, $\left(8^{\text {th }}\right.$ ed.). Boston, MA: Houghton Mufflin Company.

9. Rachal, K., Rachal, D., Daigle, S. \& Rachal, W, S. (2007). Learning problems reported by College Students: Are they learning strategies? Journal of Instructional Psychology 34(4) 191-9.

10. Richardson J.S., Morgan, R.F., Fleener, C. E. (2009) Reading to Learn in the Content Areas Wadsworth Cengage Learning.

11. Thompson, B. R., Green, P. R. (2002). Classroom strategies for identifying and helping college students at risk for academic failure. College Student Journal 36(3) 398-402. 


\section{NOTES}

